\title{
Transcending boundaries to improve the food security of HIV- affected households in rural Uganda: A case study
}

Katharine Coon

Jessica Ogden

John Odolon

Anthony Obudi-Owor

Charles Otim

See next page for additional authors

Follow this and additional works at: https://knowledgecommons.popcouncil.org/departments_sbsr-hiv

Part of the Demography, Population, and Ecology Commons, Health Policy Commons, International Public Health Commons, Medicine and Health Commons, Public Health Education and Promotion Commons, and the Social Policy Commons How does access to this work benefit you? Let us know!

\section{Recommended Citation}

Coon, Katharine, Jessica Ogden, John Odolon, Anthony Obudi-Owor, Charles Otim, James Byakigga, and Peter Spebanja. 2007. "Transcending boundaries to improve the food security of HIV-affected households in rural Uganda: A case study," Horizons Final Report. Washington, DC: Population Council. 


\section{Authors}

Katharine Coon, Jessica Ogden, John Odolon, Anthony Obudi-Owor, Charles Otim, James Byakigga, and Peter Spebanja 
Transcending Boundaries to Improve the Food Security of HIV-affected Households in Rural Uganda: A Case Study

The AIDS Support Organization of Uganda

National Agricultural Research

Organization of Uganda International Center for Research on Women Horizons Program 


\section{Transcending Boundaries to I mprove the Food Security of HI V-affected Households in Rural Uganda: A Case Study}

Katharine Coon ${ }^{1}$, Jessica Ogden ${ }^{1}$, John Odolon ${ }^{2}$, Anthony Obudi-Owor ${ }^{3}$, Charles Otim ${ }^{3}$, J ames Byakigga ${ }^{4}$, Peter Sebanja ${ }^{4}$
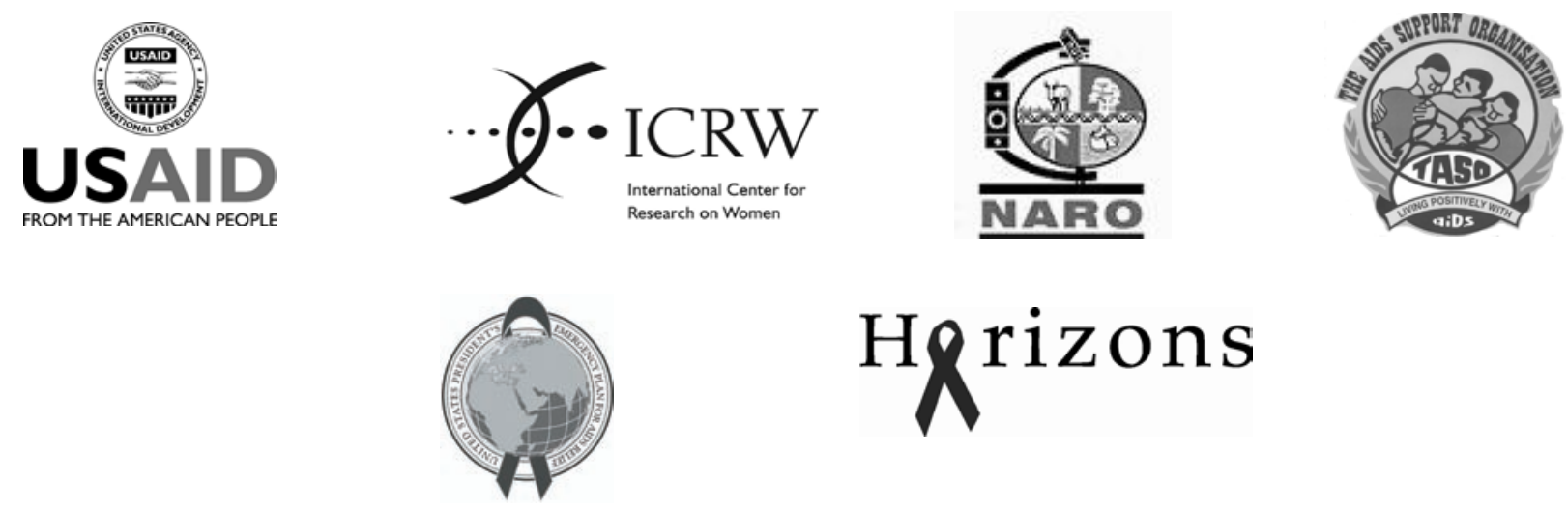

\section{Hgrizons}

${ }^{1}$ International Center for Research on Women

${ }^{2}$ New I nitiatives, Uganda

${ }^{3}$ Uganda National Agricultural Research Organization (NARO)

${ }^{4}$ The AIDS Support Organization of Uganda (TASO) 


\section{Acknowledgments}

We gratefully acknowledge the many individuals whose efforts have made the PAFOSE project and the writing of this case study possible. The project would not have been possible without the late John Aluma of NARO, Robert Ochai and Peter Sebanja at TASO Headquarters and Charlotte Johnson-Welch of ICRW—all of whom shared the vision that brought this project into being. At LIRI-NARO Dr.Charles Otim, Dr. George Mukibi-Muka and Dr. Konstantine Odongkara made significant contributions for which we are grateful. At ICRW Kathleen Kurz, Sarah Kambou and Ellen Weiss have all provided invaluable advice and support from the beginning.

We owe immeasurably to the deeply committed staffs at NARO-LIRI and at the TASO Tororo Counseling center-especially David Wakoko-Nanongo, Florence Ajok and James Byakika—all of whom have supported this project through numerous gifts of time, energy and belief in the project's mission. We also acknowledge our gratitude to the Tororo Director of Production Mrs. Eva Musenero, the Tororo District Community Development Officer Mr. Vincent Oguti, the Tororo Director of Medical Health Dr. Emanuel Okumu and Tororo District Hospital Head Nutritionist Helen Opio. Their support for this partnership has been essential to its success.

Our deepest gratitude goes to the all the PAFOSE district partners, sub-county extension partners, TASO Aids Community Workers and the farmers of Tororo, who took time to reflect on their experience and share their wisdom.

Special thanks to Anthony Obudi-Owor, Coordinator of the PAFOSE project who worked under difficult circumstances of interruptions in the funding of the project which made it take longer than originally planned.

Thanks to the consultants who gave in their time and expertise. Ross Kidd and John Odolon provided great and ongoing inspiration to the entire PAFOSE team as trainers in participatory community development. Mary Nkonge and Sarah Nagadya skillfully opened the minds of project participants to the realities of gender and the need for gender lens with HIVAIDS and food security. Finally, thanks to Ursulla Wangwe—nutrition researcher—for her contributions to the project.

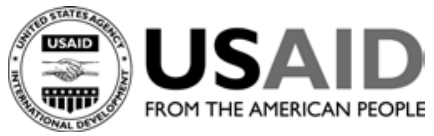

This study and final report were made possible by the President's Emergency Plan for AIDS Relief and the generous support of the American people through the United States Agency for International Development (USAID) under the terms of Cooperative Agreement No. HRN-A00-97-00012-00. The contents are the responsibility of the Horizons Program and do not necessarily reflect the views of USAID or the United States Government.

Published in July 2007.

\section{(2) Population Council}

The Population Council is an international, non-profit, nongovernmental institution that seeks to improve the well-being and reproductive health of current and future generations around the world and to help achieve a humane, equitable, and sustainable balance between people and resources. The Council conducts biomedical, social science, and public health research and helps build research capacities in developing countries. Established in 1952, the Council is governed by an international board of trustees. Its New York headquarters supports a global network of regional and country offices.

Copyright (C) 2007. The Population Council Inc.

Suggested citation: Coon, Katharine, Jessica Ogden, John Odolon, Anthony Obudi-Owor, Charles Otim, James Byakigga, and Peter Sebanja. 2007. "Transcending boundaries to improve the food security of HIV-affected households in rural Uganda: A case study,” Horizons Final Report. Washington, DC: Population Council.

This document may be reproduced in whole or in part without permission of the Population Council provided full source citation is given and the reproduction is not for commercial purposes. 


\section{Table of Contents}

$\begin{array}{ll}\text { Executive Summary } & 1\end{array}$

Introduction $\quad 3$

Food security and HIV/AIDS 3

Bridging gaps to improve food security $\quad 4$

$\begin{array}{ll}\text { Sources of data } & 5\end{array}$

$\begin{array}{ll}\text { The PAFOSE Project 2004- } 2006 & 7\end{array}$

$\begin{array}{ll}\text { PAFOSE Project aims } & 7\end{array}$

Project participants $\quad 8$

$\begin{array}{ll}\text { Project structure } & 8\end{array}$

PAFOSE's model of coordinated extension $\quad 9$

$\begin{array}{ll}\text { PAFOSE training workshops } & 10\end{array}$

The food security model $\quad 15$

$\begin{array}{ll}\text { Developing food security interventions } & 16\end{array}$

$\begin{array}{ll}\text { Outcomes and Benefits of the PAFOSE Project } & 17\end{array}$

$\begin{array}{ll}\text { Institutional outcomes and benefits } & 17\end{array}$

Outcomes on participants' skills, values, and views 19

$\begin{array}{ll}\text { Household and community outcomes } & 20\end{array}$

$\begin{array}{ll}\text { Discussion } & 27\end{array}$

What has PAFOSE accomplished through its partnership model? $\quad 27$

Why has PAFOSE worked as a partnership? $\quad 28$

Main messages and lessons learned 30

$\begin{array}{ll}\text { References } & 32\end{array}$

$\begin{array}{ll}\text { Appendices } & 33\end{array}$ 

Improving the Food Security of HIV-affected Households

\section{Executive Summary}

This report provides a case study of a process to bring key technical sectors together with communities in a partnership for reducing food insecurity among HIV-affected households in Tororo, Uganda. Food security is the ability of individuals to consume sufficient quantity and quality of food to meet their daily needs. Food security depends on the availability of food, physical and economic access to it, and the physiological utilization of nutrients.

Although knowledge and technologies exist in Uganda to better enable households to be food secure, agricultural sector programs are not promoting them as effectively as they could. Likewise, programs exist in the health and social welfare sectors to support HIV-affected households, but these do not generally incorporate the kinds of nutritional and agricultural know-how required to meet affected households' food security needs.

In response to these gaps, the National Agricultural Research Organization (NARO), the AIDS Support Organization (TASO), and the International Center for Research on Women, with support from the Horizons Program of Population Council, implemented the Partners for Food Security (PAFOSE) Project to improve household food security in rural Ugandan communities affected by HIV/AIDS. Its overall aim was to address the complexities of food insecurity and HIV/AIDS by forging partnerships across institutions at the district, sub-county ${ }^{1}$, and local levels.

The case study is based on project documents and qualitative interviews and focus group discussions conducted in May and September 2006 with PAFOSE Project participants. The partnership process described in this report involved engaging stakeholders at the district, sub-county, and community levels in a participatory training program in which participants developed a core set of partnership principles and built their capacity for working collaboratively across technical sectors. They also analyzed the key facilitators and obstacles to household food security and designed a set of social and technical interventions to address these obstacles.

Prior to the PAFOSE Project, technical sub-county extension agents (agricultural, health, and community development) had limited access to farmers. Because there is only one agricultural extension agent per sub-county $^{2}$ they have been unable to reach all households needing agricultural advisory services, especially those too stressed by illness or poverty to attend meetings in the sub-county center, where most extension activities are held. In addition, extension staff's ability to follow up on trainings, to make sure that technical information is understood and implementation problems are addressed, has been limited due to lack of sufficient numbers of trained personnel. By teaming with TASO AIDS community workers (ACWs) and other skilled resource persons who live in the communities they serve, extension agents' work with farmers has been enhanced and extended. In this way, PAFOSE functions to create a multiplier effect, such that the farmers' groups are no longer dependent on just one or two sub-county extension agents, but have expertise much closer to home.

Another of PAFOSE's key innovations has been to use registered farmers' groups as the entry point for TASO ACWs. Prior to the PAFOSE Project, ACWs held open meetings to educate community members about HIV/AIDS and encourage uptake of voluntary HIV testing and counseling. Overall, attendance was

\footnotetext{
${ }^{1}$ In Uganda, a sub-district is called a "sub-county."

${ }^{2}$ Sub-county populations in Tororo range from 25,000-30,000 people
} 


\section{Hgrizons}

sporadic, making it difficult for ACWs to develop the long-term relationships with communities necessary for increasing awareness about risk behaviors, shifting community norms about gender and sexuality, reducing stigma, and mobilizing support for HIV testing. In contrast, the farmers' groups provide TASO with a way to build the long-term relationships and trust they need within the broader community to discuss sensitive issues. Therefore coordinated extension has emerged as mutually beneficial for TASO, technical extension staff, and farmers.

Between April 2004 and May 2006 the PAFOSE district management team developed and implemented four sets of participatory training workshops which focused on:

- Principles of partnership (April 2004)

- Technical skills and knowledge sharing (June 2004)

- Detailed analysis of the causes of food insecurity in Tororo (March and April 2005)

- Identifying technical food security interventions with farmers’ groups (April 2006)

These workshops resulted in improved management capacity and more collaborative organizational structures among the district partners. This in turn created the conditions for the ACWs and other field partners to work more effectively together with farmers' groups at the local level to identify and address constraints to food security.

Four key findings emerge from the case study analysis, which provide valuable lessons for future interventions of this kind:

1. Inter-sectoral partnerships between organizations to link and leverage different sets of skills for common goals is feasible and practical. It is important that management capacity for partnership be built at all institutional levels, and that the process be participatory.

2. The coordination of agricultural extension and HIV/AIDS education and awareness can enhance the outcomes of both sets of activities.

3. Farmers' groups provide a non-stigmatizing context for conducting HIV/AIDS education, information, and sensitization activities.

4. Men and women are willing to change negative gender-related attitudes and behaviors when they understand, in terms that relate directly to their own experience, how gender inequality perpetuates household food insecurity. 


\section{Introduction}

\section{Food Security and HIV/ AI DS}

In most of sub-Saharan Africa, the HIV/AIDS epidemic has matured and the need to mitigate its impact increasingly important. HIV/AIDS is crippling the livelihood systems of households, particularly in rural communities where nearly 85 percent of the population lives (IFAD 2007). Indeed, the long-term effects of the epidemic have eroded the ability of households to produce food and other agricultural products, generate income, and care for and feed family members.

In Uganda, approximately 6.7 percent of people 15-49 years are infected with HIV. The ages most affected by the virus are 35-44 years for men and 30-34 years for women (UNAIDS 2007). Because these people are an important part of the country's productive workforce, their eventual illness and death reduces the family labor force, jeopardizing income flow and food security. The National Strategic Framework for HIV/AIDS Activities in Uganda, 2000/1-2005/6, cites studies showing that AIDS is having an impact on the amount of land being cultivated. It also reports shifts from high to low laborintensive crops, which may be less nutritious. In addition, it reports declines in production of cash crops and increasing attempts to sell food crops to generate cash income for the household (Uganda AIDS Commission 2000).

Such findings have broad implications for the food security of HIV-affected individuals and households. "Food security" is the ability of individuals to consume sufficient quantity and quality of food to meet their daily needs. Food security depends on the availability of food, physical and economic access to it, and the physiological utilization of nutrients. Food is clearly necessary for the health and well-being of all household members, but for people living with HIV, “food is medicine” (Kayita 2002). Indeed, households directly affected by HIV/AIDS commonly cite food as one of their greatest needs.

Gender plays a central role in the food security of HIV-affected households. While both men and women are actively engaged in agricultural production, women also are responsible for a range of other household activities, including family care and nutrition. When a household member becomes ill due to AIDS, women's time is increasingly diverted to care and support, and away from food production and preparation, and income-earning activities.

Technologies such as oilseed presses, solar dryers, granaries, fuel-efficient stoves, and water pumping systems have an important role to play in fostering food security because they can reduce the time expended on production tasks and overall labor burdens for men and women. Access to appropriate technologies, if coupled with training in their use, can also help vulnerable families reduce post-harvest losses and extend availability of seasonal food crops.

The agriculture sector can play a large role in mitigating the effects of the epidemic on rural households and enhancing food security (du Guerny 1999). For example, there are food crops that, when coupled with new production technologies and practices, can improve year-round supplies of nutritionally-rich food. Orange-fleshed sweet potatoes, millet, peas, pumpkins, and beans are some of these crops.

Yet having enough food to eat, even if it is of adequate quality, is not sufficient for ensuring long-term food security. Household members also need to understand the importance of a balanced diet and what it 


\section{Hgrizons}

consists of, and the importance of ensuring that all family members have equitable access to food. They also need knowledge and skills for food preparation and appropriate feeding practices.

Thus ensuring food security is a complex task that involves attention to agricultural, nutritional, gender, and technological issues.

\section{Bridging Gaps to I mprove Food Security}

Although knowledge and technologies exist in Uganda to better enable affected households to be food secure, agricultural sector programs are not promoting them as effectively as they could. Likewise, programs exist in the health sector to support HIV-affected households, but these do not generally incorporate the kinds of nutritional and agricultural know-how required to meet affected households' food security needs.

In response to these gaps, the National Agricultural Research Organization (NARO), the AIDS Support Organization (TASO), and the International Center for Research on Women (ICRW), with support from the Horizons Program, implemented a project to improve household food security in rural Ugandan communities affected by HIV/AIDS. Its overall aim was to develop a multi-sectoral partnership approach to address the complexities of food insecurity and HIV/AIDS by forging partnerships across institutions at the district, sub-county, and local levels.

The National Agricultural Research Organization (NARO) develops agricultural technologies to improve farm productivity, production, and profitability. Some of these technologies reduce time and labor burdens. Others improve the nutrient value of crops, while still others reduce post-harvest losses. NARO coordinates with institutions that provide outreach services which support farmers' adoption of agriculture technologies and practices. The AIDS Support Organization (TASO) is a non-governmental organization in Uganda founded to improve the quality of life of people living with HIV/AIDS and HIV/AIDS-affected communities. TASO's services include counseling, basic medical care, and social support. Clients can also receive food supplements and skills training. The International Center for Research on Women (ICRW) is a non-governmental research organization that links research and advocacy to produce evidence-based solutions to advance gender equality across development sectors.

Each organization had specific reasons for undertaking this project. TASO wanted to establish linkages with Uganda's agricultural research and extension institutions to improve its capacity to deliver agricultural resources to HIV-affected households in order to:

- Reduce dependence of people living with HIV on food aid.

- Provide them with the skills and tools they need to improve their own food security.

- Improve nutrition among a greater number of people living with HIV not just a small fraction reached by food aid.

NARO's objectives for the project focused on finding ways to improve dissemination of appropriate technologies already available in Uganda, and reach poor, HIV-affected farmers despite bottlenecks in 
national agricultural extension and Uganda's shift to a privatized model of extension delivery. Like TASO, NARO was also concerned with finding long-term solutions to food insecurity that build on Uganda's own resources. Both TASO and NARO saw a partnership strategy as a way to begin linking different sets of institutional capacities for this purpose.

ICRW's objectives were to contribute to creating a sustainable model for improving the food security of HIV-affected households by improving practitioners' understanding of how gender impacts food security.

The mission of the resulting project, known as Partners for Food Security (PAFOSE), was to increase collaboration and synergy through a partnership between district-level organizations. This partnership would then link extension agents from the different partner organizations to each other, and to farmers' groups, to identify and promote ways to improve food security using approaches that integrate knowledge of HIV/AIDS, gender, nutrition, and agricultural extension. PAFOSE's efforts to forge an effective, multi-agency partnership and the outcomes of this approach are the subjects of this case study. The specific aims of the case study are to:

- Describe activities undertaken by the PAFOSE Project in Tororo between 2004 and 2006 to forge a multi-agency partnership.

- Describe the model to improve food security developed and used by the partnership.

- Discuss key outcomes and benefits of the partnership-building process for the participating institutions.

- Describe perceived changes in attitudes and behaviors related to food security and HIV/AIDS by project participants.

- Highlight key lessons from the project’s experience to date.

\section{Sources of Data}

The material to meet the first two aims of the case study is derived from project documents, which include technical reports submitted to the Horizons Program, and internal reports and records of project meetings and activities.

Findings on perceived project outcomes and changes are based on qualitative interviews and group discussions held with project partners in Tororo between May and September 2006. Informants were asked to reflect on PAFOSE activities since 2004; their perspectives of the partnership approach; and effects of the PAFOSE Project on their organizations, on how they conduct their work, and on changes in attitudes and behaviors linked to HIVAIDS and food security in the PAFOSE farmers' groups.

During two weeks in May and one in September, members of the research team held more than a dozen discussions with district partners from the five participating district institutions: TASO; NARO; and the district government's Agricultural Production, Health, and Community Development Departments.

Between June and July they also conducted a group discussion with six district partners, including at least one from each of the five participating district institutions, specifically on project outcomes. In addition, the researchers conducted a total of eight formal individual interviews: six with representatives from participating district institutions, one with a sub-county agricultural extension agent, and one with one of TASO's AIDS community workers. Handwritten notes, backed by digital recordings, were taken during formal interviews. Informal discussions were recorded by a combination of handwritten notes, field notes written each day, and in some cases recordings made on a small digital voice recorder. 


\section{Hgrizons}

In May and September, the researchers also held six group discussions with TASO's AIDS community workers and farmer's group members to discuss their impressions of the PAFOSE Project and its outcomes. There were approximately 15-20 people in each group. The groups were organized by PAFOSE district partners, and the discussions were facilitated and translated by members of the PAFOSE district and sub-county teams. Everyone attending these groups had been involved with the PAFOSE Project for some time and the purpose of the meetings was very clearly stated before the meetings began. Informants came from two of the three PAFOSE intervention sub-counties, Paya and Busaba. 


\section{The PAFOSE Project 2004- 2006}

\section{Project Location}

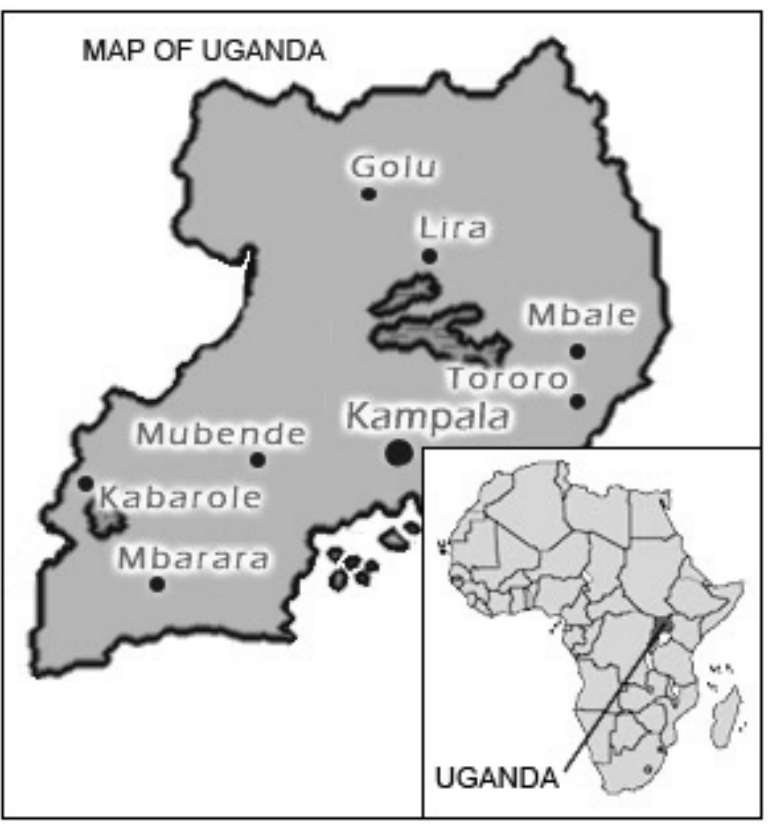

NARO and TASO chose to locate the project in Tororo District in Eastern Uganda because both organizations have strong bases there on which to build. The district includes TASO's clinic for the Eastern Region and NARO's Livestock Research Institute (LIRI). Additional resources include the Tororo District Hospital, an active District Government with technical extension branches in agriculture, health, and community development; and registered farmers' groups that were established under the Danish International Development Agency's (DANIDA) Household Agriculture Support Program (HASP), which targeted the "poorest" households, including those affected by HIV and those headed by women. Eighty-two percent of the land in Tororo is under smallholder cultivation, and according to a recent survey, 36 percent of households fall into the "poorest" category and are food insecure either part or all of the year (Ravnborg 2004). HIV prevalence in Eastern Uganda is estimated to be 6.2 percent among women and 4.4 percent among men ages 15-49 years (MOH and ORC Macro 2006).

\section{PAFOSE Project Aims}

The project was designed to bring together relevant knowledge and technologies from the agricultural sector (NARO) with knowledge and experience in delivering community-based HIV/AIDS treatment, care, and support services (TASO). The project hypothesized that interventions integrating knowledge, technologies, and program experiences from the two groups can improve the food security of households in rural Uganda and thereby mitigate the impact of HIV/AIDS. The project aimed to engage key staff from the relevant technical institutions in a participatory training process to strengthen their capacity to work cooperatively across sectors, and to develop strategies that bring all the necessary resources together to address food security needs at the community level. To accomplish this, the project would do the following:

- Create a functional, interagency partnership between organizations with expertise in HIV/AIDS, agriculture, nutrition, and gender

- Use the partnership to identify and implement strategies at the community level to improve the food security of HIV-affected farming households in place of independent sectoral efforts. 


\section{Hgrizons}

\section{Project Participants}

To meet their objectives, the PAFOSE Project targeted four groups for project activities:

- The directors and senior staff of five district organizations based in central Tororo MunicipalityTASO-Tororo, NARO-LIRI, the district government's Agricultural Production Department, the District Directorate of Health Services, and the district government's Community Development Department. These five organizations are referred to as the district partners.

- Government technical extension agents working for the district's Agricultural Production, Health, and Community Development Departments. They live and work in the sub-county trading and administrative centers. These extension agents are referred to as the sub-county extension partners.

- TASO's AIDS Community Workers (ACWs) and other skilled resource persons knowledgeable in sanitation, agriculture, or adult literacy programs, who live and work in the local farming communities. These individuals are referred to as the ACWs and other field partners. ${ }^{3}$

- Farmers' groups - the ultimate beneficiaries of the partnership. Members of these groups include women and men, as well as some ACWs.

\section{Project Structure}

The PAFOSE Project is managed by a project coordinator, who is based at LIRI, and overseen by the district management team (DMT), which comprises senior staff within the five district-level partner institutions. The DMT is made up of approximately 15 individuals, including:

- Director and staff from TASO Tororo clinic (4);

- Director and staff from LIRI (4);

- Director and staff from the Tororo District Agricultural Production Office (3);

- District Health Educator, appointed to the team by the District Health Director (1);

- Head of Nutrition at the Tororo District Hospital, also appointed to the team by the District Health Director (1); ${ }^{4}$ and

- Director and staff of Tororo District Community Development Office (2).

The DMT and project coordinator (who is also a member of the DMT) take primary responsibility for planning, managing, and implementing all significant aspects of the project.

\footnotetext{
${ }^{3}$ TASO AIDS Community Workers (ACW) make up the majority ( 20-24) of the ACWs and other field partners in each of the three intervention sub-counties.

${ }^{4}$ Both the district health educator and the head of nutrition at the Tororo District Hospital participate in PAFOSE as representatives of the District Health Department, which is one of the five participating district institutions.
} 


\section{Selection of sub-counties and farmers' groups}

The PAFOSE DMT selected three of Tororo's 13 sub-counties (Paya, Busaba, and Osukuru) in which to use the PAFOSE Partnership to help HIV-affected households improve their nutrition and food security. They also selected nine farmers' groups in Paya, nine in Busaba, and seven farmers' groups and two TASO post-test clubs in Osakuru to work with PAFOSE ${ }^{5}$. The 27 farmers' groups participating in the project contain approximately 1,000 individual members, with 35-40 farmers in each group. The DMT based selection of PAFOSE farmers' groups on the following criteria:

- Groups were registered with Tororo’s Agricultural Production Office, and were already established and working together prior to the PAFOSE Project.

- Groups had been formed under DANIDA's HASP, and so contained high percentages of HIV-affected households.

- Groups included women only, men only, mixed men and women, and youth groups, so that all segments of the HIV-affected community would be included.

Since HIV status is not a criterion for membership in HASP farmers' groups, the groups working with PAFOSE included among their members people living with HIV as well as those whose HIV status is not known. The decision not to make HIV status a criterion for participating in the project was made for several reasons, including:

- Stigma: If only HIV-positive people had been eligible for the project, fear of being identified as HIVpositive might have prevented people from participating.

- Expanding HIV/AIDS education and HIV testing: By working with HASP farmers' groups, PAFOSE could disseminate information to more people and promote HIV testing to people who may not already be aware of their HIV status.

- Building community solidarity and resilience in face of the AIDS epidemic: By having mixed groups of HIV-positive and HIV-negative farmers and those of unknown status work together to improve food security, this may help foster the integration of people living with HIV back into the community, while building community capacity to respond to the epidemic.

\section{PAFOSE's Model of Coordinated Extension}

The PAFOSE Project has implemented a coordinated extension model whereby TASO's ACWs work with the technical sub-county extension agents to provide farmers' groups with ongoing education and support around both food security and HIV/AIDS. Ever since the first set of PAFOSE workshops on partnership (see next section), the PAFOSE ACWs and other field partners and sub-county extension partners have coordinated extension outreach activities together, rather than working separately, as they did before the PAFOSE Project began. PAFOSE's subsequent workshops continued to reinforce the ability of ACWs and other field partners and the sub-county extension partners to plan and implement a coordinated approach to extension in their communities.

Prior to the PAFOSE Project, technical sub-county extension agents (agricultural, health, and community development) had limited access to farmers. Because there is only one agricultural extension agent per sub-county ${ }^{6}$ they have been unable to reach all households needing agricultural advisory services,

\footnotetext{
${ }^{5}$ Because most members of the TASO post-test clubs are farmers, references to farmers' groups in the rest of the report include the two TASO post-test clubs.

${ }^{6}$ Sub-county populations in Tororo range from $25,000-30,000$ people.
} 


\section{Hgrizons}

especially those too stressed by illness or poverty to attend meetings in the sub-county center, where most extension activities are held. In addition, extension staff's ability to follow up on trainings, to make sure that technical information is understood and implementation problems are addressed, was limited due to lack of sufficient numbers of trained personnel. By teaming with ACWs and other skilled resource persons who live in the communities they serve, extension agents' work with farmers has been enhanced and extended. In this way, PAFOSE functions to create a multiplier effect, so that the farmers' groups are no longer dependent upon just one or two sub-county extension agents, but have expertise much closer to home.

Another of PAFOSE's key innovations has been to use registered farmers' groups as the entry point for TASO ACWs. Prior to the PAFOSE Project, ACWs held open meetings to educate community members about HIV/AIDS and encourage uptake of voluntary HIV testing and counseling. ${ }^{7}$ Overall, attendance was sporadic, making it difficult for ACWs to develop long-term relationships with communities necessary for increasing awareness about risk behaviors, shifting community norms about gender and sexuality, reducing stigma, and mobilizing support for HIV testing. In contrast, the farmers' groups provide TASO with a way to build the long-term relationships and trust they need within the broader community to discuss sensitive issues. Therefore coordinated extension has emerged as mutually beneficial for TASO, technical extension staff, and farmers.

\section{PAFOSE Training Workshops}

The mechanism for creating an inter-sectoral partnership was a series of participatory training workshops developed, planned, and implemented by the DMT. These workshops resulted in improved management capacity and more collaborative organizational structures among the district partners. This in turn created the conditions for the sub-county extension partners and ACWs and other field partners to work more effectively together with farmers' groups to identify and address constraints to food security.

Between April 2004 and May 2006 the PAFOSE DMT developed and implemented four sets of participatory training workshops which focused on:

- Principles of partnership (April 2004)

- Technical skills and knowledge sharing (June 2004)

- Detailed analysis of the causes of food insecurity in Tororo (March and April 2005)

- Identifying technical food security interventions with farmers’ groups (April 2006)

The workshops served as a vehicle for the different partners to share their technical expertise and develop an integrated approach to food security based on partnership principles. At the same time, the coordination required to plan and implement the workshops has built the management capacity of district, sub-county, and community actors from different agencies to work together to develop and implement food security interventions. This, together with the fact that the structure ensured frequent contact between district partners, sub-county extension partners, and ACWs and other field partners, has strengthened the partnership as a whole. The first and third workshops were facilitated by two consultants experienced in participatory adult learning methodologies, participatory project design and management,

\footnotetext{
${ }^{7}$ TASO ACWs' mobilization activities are in addition to home based support and care for people living with HIV/AIDS and their caregivers. Mobilization targets the community at large, to expand education and awareness of HIVAIDS, to encourage testing, and to open spaces to discuss and raise consciousness of high risk behaviors. Home-based care services provide registered TASO clients and their caregivers with support in their homes.
} 
and community-based resource management; but the rest were developed and implemented by the partners themselves.

The project used a cascading trainer of trainers organizational model to reach the different target groups for each of the four sets of workshops. First, members of the district-level partner organizations and subcounty extension partners were trained in the workshop content in workshops held in Tororo Municipality. Nine of those trained became master trainers. These nine, supported by the rest of the DMT, were then responsible for training the ACWs and other field partners in workshops held in the sub-county centers. Trained ACWs and other field partners then worked together in teams of two or three, using the knowledge and skills they gained from the workshops to work with one local farmers group on an ongoing basis.

Table 1 Summary of key information about the four sets of training workshops

\begin{tabular}{|l|l|l|l|l|}
\hline & $\mathbf{1}^{\text {st }}$ workshop & $\mathbf{2}^{\text {nd }}$ workshop & $\mathbf{3}^{\text {rd }}$ workshop & 4th workshop \\
\hline Title & $\begin{array}{l}\text { Principles of } \\
\text { Partnership }\end{array}$ & $\begin{array}{l}\text { Technical Skills } \\
\text { and Knowledge } \\
\text { Sharing }\end{array}$ & $\begin{array}{l}\text { Understanding } \\
\text { Causes of Food } \\
\text { Insecurity }\end{array}$ & $\begin{array}{l}\text { Identifying Food } \\
\text { Security } \\
\text { Interventions }\end{array}$ \\
\hline Aims & $\begin{array}{l}\text { Establish } \\
\text { principles and } \\
\text { procedures of } \\
\text { partnership }\end{array}$ & $\begin{array}{l}\text { Share technical } \\
\text { expertise among } \\
\text { district and sub- } \\
\text { county extension } \\
\text { partners }\end{array}$ & $\begin{array}{l}\text { Analyze causes of } \\
\text { food insecurity, } \\
\text { identify } \\
\text { interventions, } \\
\text { develop action } \\
\text { plans }\end{array}$ & $\begin{array}{l}\text { Identify technical } \\
\text { food security } \\
\text { interventions to } \\
\text { implement through } \\
\text { PAFOSE }\end{array}$ \\
\hline
\end{tabular}

\section{District level workshops held in Tororo Municipality to train master trainers}

\begin{tabular}{|l|l|l|l|l|}
\hline & $\mathbf{1}^{\text {st }}$ workshop & $\mathbf{2}^{\text {nd }}$ workshop & $\mathbf{3}^{\text {rd }}$ workshop & $\mathbf{4}^{\text {th }}$ workshop \\
\hline Date held & April 2004 & June 2004 & April 2005 & April 2006 \\
\hline $\begin{array}{l}\text { \# district and } \\
\begin{array}{l}\text { sub-county } \\
\text { extension } \\
\text { partners } \\
\text { trained }\end{array}\end{array}$ & $\begin{array}{l}\text { 11 district partners } \\
\text { 9 sub-county } \\
\text { extension partners }\end{array}$ & $\begin{array}{l}\text { 11 district partners } \\
\text { 9 sub-county } \\
\text { extension partners }\end{array}$ & $\begin{array}{l}\text { 4 district partners } \\
5 \text { sub-county } \\
\text { extension partners }\end{array}$ & $\begin{array}{l}10 \text { district partners } \\
5 \text { sub-county } \\
\text { extension partners }\end{array}$ \\
\hline
\end{tabular}

\section{Sub-county workshops held in sub-county centres to train ACWs and other field partners}

\begin{tabular}{|l|l|l|l|l|}
\hline & $\mathbf{1}^{\text {st }}$ workshop & $\mathbf{2}^{\text {nd }}$ workshop & $\mathbf{3}^{\text {rd }}$ workshop & $\mathbf{4}^{\text {th }}$ workshop \\
\hline Dates held & $\begin{array}{l}\text { April and June } \\
2004\end{array}$ & N/A & $\begin{array}{l}\text { April and October } \\
2005\end{array}$ & April 2006 \\
\hline $\begin{array}{l}\text { \# ACWs and } \\
\text { other field } \\
\text { partners } \\
\text { trained }\end{array}$ & $\begin{array}{l}\text { 24 ACWs and } \\
\text { other field partners } \\
\text { per sub-county (72 } \\
\text { total) }\end{array}$ & $\begin{array}{l}\text { No level-two } \\
\text { trainings for this } \\
\text { workshop }\end{array}$ & $\begin{array}{l}\text { 24 ACWs and } \\
\text { other field partners } \\
\text { per sub-county (72 } \\
\text { total) }\end{array}$ & $\begin{array}{l}\text { 24 ACWs and other } \\
\text { field partners per } \\
\text { sub-county (72 } \\
\text { total) }\end{array}$ \\
\hline
\end{tabular}

See Appendix 1 for detailed tables of PAFOSE master and sub-county workshops/trainings 


\section{Hgrizons}

\section{Launching the partnership}

The initial workshop to launch the partnership was held in April 2004 and focused on establishing principles and procedures (see Appendix 2 for the agenda). This workshop played an important role in establishing how the various institutions would relate to one another and how the project would be coordinated. The primary objective was to get the key stakeholders at the district level to discuss their ideas and expectations about the partnership, to create a set of principles and guidelines, and to create a plan for implementing the partnership. At the same time the workshop sought to initiate the process of developing relevant skills and attitudes for the partnership. The outcomes and outputs of the workshop were:

- Agreement on a partnership model for the project, including a set of 11 principles of partnership (see Box 1).

- Guidelines for practical implementation of partnership principles including:

0 The identification of roles and responsibilities for each partner.

0 The generation of a results framework and set of indicators for the partnership (see Appendix 3).

- Two training manuals for use by master trainers and ACWs and other field partners, covering principles of partnership, participatory skills building, and situation analysis and action planning for food security. ${ }^{8}$

\section{Box 1 PAFOSE Principles of Partnership}

1. Accountability

2. Willingness to listen to various viewpoints

3. Common purpose

4. Common values

5. Valuing others' technical expertise

6. Belief that partnership can make a difference

7. Trust in each other

8. Belief in the partners' willingness to work with each other

9. Commitment to making it work

10. Transparency

11. Perceived rewards or benefits

The second objective of the kick-off workshop was to build the training capacity of the master trainers: expand their skills in participatory training, deepen their understanding of the field work tasks, and plan the workshops for the ACWs and other field partners to be implemented after the districtlevel master trainings. Here the key outcomes were:

- Clear understanding by the master trainers of their roles in training and coaching the ACWs and other field partners and monitoring the program.

- Consolidation of training teams, including development of joint planning and teamwork.

- Enhancement of trainers' skills for developing training curricula and for using participatory training techniques.

The third objective of the kick-off workshop was to begin deepening the participants' understanding of the food security situation in Tororo district— to inform the subsequent food

\section{Box 2 Six major goals of participatory training} workshop

GOAL 1: Build consensus on a locally relevant and realistic partnership model that includes principles and practical guidelines;

GOAL 2: Develop skills, attitudes, approaches and commitment for building effective partnership;

GOAL 3: Develop a plan of action for implementing partnership on a practical basis;

GOAL 4: Develop an integrated understanding of food security problems, root causes and possible solutions;

GOAL 5: Strengthen the participatory training skills of trainers i.e. skills to design and facilitate training courses at the sub county level;

GOAL 6: Develop training manuals for the field partner workshops.

\footnotetext{
${ }^{8}$ The first two of five training manuals produced by the PAFOSE district partners were outcomes of this workshop. One was for master trainers to use when they conducted trainings in the sub-county centers for ACWs and other field partners, and the other was a resource for the ACWs and other field partners to guide their work with the PAFOSE farmers' groups.
} 
security interventions - as the first step toward facilitating the same process with ACWs and other field partners, and later farmers' groups. Participants examined factors influencing food security in their own lives and communities, and used this as the basis for their participatory exercises and discussions. What developed from this was:

- An integrated understanding of the food security situation in Tororo which included an analysis of how gender, nutrition, and HIV/AIDS impact the livelihoods of households and communities.

- Development of a strategy for working with farmers' groups in each sub-county.

After participating in the district-level workshop as trainees, master trainers led the same process in each of the three intervention sub-counties to train the ACWs and other field partners. The sub-county training workshops were held in two rounds, the first in April 2004 and the second in June 2004. The first round of workshops introduced ACWs and other field partners to partnership principles and to an integrated understanding of food security, and developed their participatory skills. In the second round of workshops ACWs and other field partners were trained in situation analysis and action planning to identify causes of food insecurity, community coping mechanisms, and interventions to improve food security. The second round of workshops also developed ACWs and other field partners' skills in farmer group mobilization and support. The ACWs and other field partners, supported by their master trainers, then used the participatory approach, partnership principles, and informational content of the PAFOSE trainings in their meetings with the PAFOSE farmers' groups.

\section{Subsequent workshops}

The initial workshop established the model followed by subsequent workshops, including procedures for developing content based on each partner's technical expertise and on partners' own investigationsinformed by HIV, nutrition and gender lenses - into the food security situation in their communities, as well as use of the trainer of trainer model to link the district, sub-county, and ACWs and other field partners. Even though the content of the subsequent workshops focused on food security, the 11 principles of partnership continued to be reinforced as the basis of all PAFOSE activities. In addition, subsequent workshops continued to strengthen the partners' capacity to function effectively in the teams and roles laid out in the first workshop, and to use participatory methods effectively.

The objective of the second workshop organized by the district team was to build a common pool of shared technical information among PAFOSE district and sub-county partners so that all had confidence to speak about others' technical specialties when working with ACWs and other field partners.

The objective of the third set of workshops was to develop the skills and training modules needed by ACWs and other field partners to help farmers' groups a) identify and think critically about the causes of food insecurity, b) identify community coping mechanisms, c) identify social and technical interventions, and d) develop criteria for prioritizing and choosing interventions to implement. Training modules were developed around crop and animal production issues; harvest and household food losses; nutrition analysis of food gaps in farmers' diets and causes of food gaps; and gender issues, including improving the collaboration between men and women to improve food security.

The four criteria for selecting interventions to implement with farmers' groups that emerged from the workshops were:

- Is appropriate for the target group (resource poor, AIDS-affected households)

- Addresses production (availability), accessibility, and utilization (nutrition) 


\section{Hgrizons}

- Is gender responsive (e.g., reduces women's workload, increases women's role in household decision making)

- Is low cost (inputs can be covered by project budget)

The objective of the fourth round of workshops and trainings, which began in April 2006, has been to finalize selection of the technical interventions and initiate their implementation by PAFOSE. In April 2006 ACWs and other field partners and farmers wrote lists of technical interventions they felt would have the largest impact on their food security, derived through the integrated analysis and action planning developed by PAFOSE in the preceding trainings. At the same time the PAFOSE district and sub-county extension partners developed criteria for making a final selection of interventions from the lists developed by the ACWs and other field partners working together with the farmers. After prioritizing the interventions, the district partners developed procedures to purchase and distribute materials (such as improved poultry stock, improved seed) needed for the technical interventions to the PAFOSE farmers' groups with remaining project funds. In June and July 2006 the PAFOSE district partners developed a technical manual for ACWs and other field partners with modules on production practices for each of the technical interventions, and held master trainings on use of the manuals. In December they began ongoing sub-county trainings to teach ACWs and other field partners the content of the technical modules, provide ongoing support to ACWs and other field partners as they work with farmers' groups to implement the interventions, and work with ACWs and other field partners and farmers to monitor and evaluate the interventions.

\section{Training manuals and modules}

Altogether, the PAFOSE district partners produced five training manuals: two for master trainers to use when training ACWs and other field partners, and three for ACWs and other field partners to use in their work with their farmers' groups (see Appendix 1). The first four manuals contain workshop agendas and training modules containing lesson plans on partnership, food security analysis, situation analysis (information gathering conducted by ACWs and other field partners to deepen food security analysis), action planning, and skills training for mobilizing farmers' groups. Included in all the manuals are tips on group facilitation and participatory techniques. The fifth manual contains modules on each of the technical interventions identified by the PAFOSE organization to promote among PAFOSE farmers' groups, including improved poultry breeds, improved maize and soybean seeds, draught animals, orange fleshed sweet potato root stock, fruit and fuel trees for planning around homesteads, improved goat breeds, and low-cost fuel efficient cook stoves.

\section{PAFOSE approach to ACWs and other field partner training}

The PAFOSE approach to training ACWs and other field partners was modeled on TASO's methods for training its ACWs. ACWs and other field partners were given time to master the content of each new workshop before the next one was added. Most importantly, the trainings emphasized to ACWs and other field partners the importance of giving farmers the time, attention, and skilled facilitation they need to absorb, discuss, and process the information and ideas in each of the PAFSOE training manuals over the course of several farmer group meetings. In this way, PAFOSE workshops aimed to build understanding of the connections between HIVAIDS, nutrition, gender, and food security among participating farmers in ways that would empower farmers to examine their own behaviors and identify changes to improve their own food security and nutrition. 
Improving the Food Security of HIV-affected Households

\section{The Food Security Model}

According to project documents, including those from planning meetings held in March 2004, PAFOSE district partners embraced the broadly used definition of food security, as an individual's access to sufficient, safe, and nutritious food to meet their dietary needs for an active and healthy life in a culturally appropriate way. At the same time they decided to analyze food security in terms of availability, accessibility, and utilization. Availability referred to the physical supply of food, accessibility to people's ability to access to foods that are physically present, and utilization to the biological level of nutrition and absorption. The partners took these basic definitions as the starting point for their own approach, which they refined in the course of the level-one and level-two workshops and trainings.

As described in project reports, partners understood availability as determined by the types of crops and livestock produced in Tororo, the production technologies used, and the management of field tasks and of post-harvest processing and storage. Utilization was discussed in terms of nutrition needed to maintain health, especially for people living with HIV/AIDS. Toward this end, PAFOSE training modules included information on the different food groups, the importance of dietary diversity to health, and the nutritional needs of people living with HIV/AIDS. PAFOSE trainings also addressed safe food handling in order to prevent food spoilage and good hygiene to prevent food contamination when preparing or handling food. Project documents describe access to food as dependent on gendered sharing practices within households and on food beliefs and taboos about which foods are appropriate for consumption by different categories of people, such as men, children, pregnant women, or women in general. Finally, PAFOSE training manuals and workshop reports suggest that partners used a gender lens to analyze all aspects of food security (availability, accessibility, and utilization) and all causes of food insecurity.

During PAFOSE workshops and trainings participants identified causes of food insecurity using "food loss analysis" to identify inefficient or wasteful practices in crop and livestock production, harvest and post-harvest activities and home food management. Likewise, "nutritional gap analysis” was used to identify categories of foods are that are insufficiently produced or consumed. "Gender roles analysis" was used to help participants understand how unequal workloads and decision making contribute to food losses, and how unequal food sharing within homes contributes to nutritional gaps.

The PAFOSE approach to food security emphasized the inter-relatedness of farming, household food management practices and gender inequality in causing people to experience food insecurity. For example, as described in reports of level-two trainings, ACWs and other field partners identified:

- Women's “work overload” and men's disengagement from farming activities as causes of sub-optimum farming and post-harvest practices and lower yields.

- Women's exclusion from decision making as causes of conflict with their partner, domestic violence, and stealing food from household stores by both men and women for impulse sales of crops at low prices, all of which contribute to insufficient food for the family.

- Cultural "feast-to-famine” practices including overcooking, over-brewing, over-giving at harvest, overselling of crops and animals, and excessive time taken for funerals as causes of insufficient food for the family.

This integrated understanding of the causes of food insecurity has been especially important in helping PAFOSE partners and farmers identify and learn new behaviors to improve food security. One of the male ACWs or other field partners from Busaba expressed this when he said: "PAFOSE has helped us to understand how we ourselves cause our own poverty, and so we are able to see how we ourselves must change it." 


\section{Hgrizons}

\section{Developing Food Security I nterventions}

The original concept of the project was that in order to be truly sustainable the food security interventions developed by the partnership should not require additional, externally provided, inputs. The argument was that simply improving access to and understanding of existing knowledge and technology would have a positive effect on household food security. However, from the outset the partners in Tororo argued that providing "hard" inputs (such as improved seed and other technologies) should form a fundamental component of the interventions. Through the partnership process, the PAFOSE partners developed their own approach, which effectively combined both positions to foster sustainability. Through the food security and gender analysis process, PAFOSE determined that two types of interventions were required: one which focused on changing social norms and prevailing behavior patterns which contributed to food insecurity and the other which focused on introducing new technical and technological strategies. The first set of interventions is referred to by PAFOSE as "social interventions" and the second as "technical interventions."

PAFOSE defines social interventions as those which "address socially determined food losses.” Examples of socially determined food losses include excessive celebrations at harvest time, or women's work overload causing production or post-harvest losses. During the group discussions held with PAFOSE ACWs and other field partners and farmers in May and September 2006, informants indicated that social interventions take place in the context of ACWs and other field partners' interactions with farmers' groups. These include skills building for household food management, which can reduce food losses and improve nutrition without purchased inputs, but they also include efforts to shift gender norms.

Technical interventions include the transfer of real inputs or resources to help households increase food availability and incomes, along with the technical knowledge and skills needed to use the inputs effectively. Technical interventions identified by PAFOSE target improvements in farming practices such as using improved seeds or livestock breeds, using draught power, planting hybrid fruit trees, placing vegetable gardens and fuel lots near houses, and promoting the use of simple, affordable fuel efficient stoves.

During PAFOSE's fourth workshop, held April-May 2006, the district and sub-county extension partners prioritized several technical interventions, identified by the PAFOSE farmers' groups, to finance as resources become available. In order of priority they are: improved poultry breeds for increased egg and chicken production; improved maize and soybean seed; draught animals along with ploughs, planters, weeders, and wagons; root stock for orange fleshed sweet potatoes; fruit and fuel trees for planting around homesteads; improved goat breeds for meat production; and low-cost fuel efficient cook stoves. As of September 2006 the PAFOSE partners had acquired financial resources to begin sourcing inputs for the technical interventions and planned to distribute them to the farmers' groups in 2007. 


\section{Outcomes and Benefits of the PAFOSE Project}

\section{Institutional Outcomes and Benefits}

Outcomes of the partnership intervention seen at the district, sub-county, and local levels include changes in coordination within each level of the district's socio-political structures and management hierarchies as well as changes in the ways communication and support flow between levels.

\section{Institutional changes at the central district level}

Obvious institutional changes include the willingness and commitment of different departments and agency leadership within TASO and NARO to:

- Release key staff to PAFOSE coordination meetings, workshops, and field activities with ACWs and other field partners and farmers' groups

- Release and share resources, especially vehicles for transport from the district center to outlying subcounties. Transport is an expensive, limiting factor in the ability of government staff to get around the district, which is why sharing these resources effectively is an important outcome of the partnership.

TASO provides PAFOSE with significant staff time for key managerial activities, as well as supporting PAFOSE's field activities with the use of vehicles to help carry different partners, including those from government agencies, to the field. NARO-LIRI provides PAFOSE with critical administrative support to manage project finances and maintain project records. In addition, now that the technical interventions have begun, NARO is providing support with monitoring and evaluating the impact of the interventions, as well as support sourcing the agricultural inputs for the interventions and providing PAFOSE with the technical knowledge and skills needed to use the inputs effectively. In summer of 2006 TASO and NARO signed a Memorandum of Understanding for the first time, formalizing their commitment to function as institutional bases for PAFOSE.

Involvement of [the different] partners is useful, and this has brought success. As we are able to work together, we are able to identify our own roles, and we respect the other partners' presence in PAFOSE. We were able to train partners, identify [food security] problems and interventions. When funding changed hands we were able to involve partners not originally part of this project...this wouldn't have been possible if the partnership had not been strong enough.

Dr. Otim, Director, LIRI

In the case of the district government's Agricultural Production and the Community Based Development Offices, the directors are themselves active members of PAFOSE's district management team, so commitment to the partnership's principles and goals are directly reinforced in these agencies, and both directors also support participation of their subordinates in PAFOSE activities. The director of the district Health Department has appointed two staff to the project, but as of 2006 the department as a whole had not been as closely involved as Agricultural Production and Community Development. 


\section{Hgrizons}

The principles of the partnership and the coordinated approach to extension provide the basis for PAFOSE's own activities, but they are also beginning to influence management practices in routine work outside of PAFOSE. For example, staff from partnership agencies have:

- Coordinated routine visits to sub-counties so that vehicles can be shared.

- Delivered messages or packages for one another.

- Assisted one another with collection of household level data from the field.

An outcome of this process mentioned by several partners is that time is used more efficiently, both of government staff, and of members of local farming communities, who no longer have to stop their work to attend meetings called by each government agency separately.

When we [TASO field staff and the district's technical extension staff] arrange meetings with clients, they happen to be the same farmers in the community, so we don't have to make separate meetings. This saves time and money. We staff from TASO even share our transport with district staff going in the same direction.

PAFOSE district partner, TASO

PAFOSE's commitment to broadening knowledge and skills of technical field staff beyond narrow specializations is also beginning to occur beyond the activities of PAFOSE itself. For example, Tororo District Hospital held workshops for its nutrition and community health field staff on simple techniques for increasing homestead food production. This was done at the instigation of the Hospital's director of nutrition, who is an active member of PAFOSE's district management team, after her experience with technical skills sharing in PAFOSE.

\section{Institutional changes at the sub-county level}

PAFOSE's most important outcome at the sub-county level can be seen in the system of coordinated extension developed as an outcome of the partnership intervention. Key outcomes of coordinated extension include:

- Coordinated planning between PAFOSE ACWs and other field partners and technical extension agents, which has greatly expanded the ability of extension agents to connect with farmers' groups and households.

- Improved two-way flow of information between technical extension and farm households, which enables farmers to direct questions and concerns to extension specialists via the ACWs and other field partners, and to receive responses far more rapidly and effectively than in the past.

Sub-county extension agents, ACWs and other field partners and members of PAFOSE farmers' groups all describe contact between technical extension and farmers prior to PAFOSE as occurring infrequently, and then mostly limited to farmers with the means (time and transport) to get to the sub-county centers, which tended to exclude AIDS-affected farmers too ill to travel and women as a result of gender norms that restricted their mobility. Through the ACWs and other field partners, who are also part of the farmers' communities and therefore are in regular contact with them, PAFOSE has created a mechanism for regular communication and feedback between farmers' groups and technical extension which greatly 
facilitates the transfer of knowledge and skills, along with bringing previously marginalized farmers into contact with extension.

It is now easier to mobilize farmers for meetings, as communication is much better.

Sub-county extension partner, Busaba

In addition to improved communication, sub-county extension partners and ACWs and other field partners report that the quality of the information delivered by PAFOSE is much higher than the quality of the information delivered by single agencies prior to PAFOSE, and from their perspective this is a very important outcome of the partnership. Prior to PAFOSE, technical agencies (both government and NGO) would provide educational workshops in the sub-counties for farmers, but the information related only to the agency or NGO's focus or technical specialization. Workshops were infrequent, and typically several months elapsed before another agency would hold a workshop on another topic. Because information was uncoordinated and delivered erratically, without follow-up, farmers found it difficult to draw connections or apply the education to their own lives.

Before PAFOSE an NGO might come and give a sensitization on gender. Then nine months later another would come and sensitize on production, but by then we had forgotten what was said about gender, and so we couldn't see the connections. Now we have it all together, and can see the connections.

Female ACW or other field partner, Paya

\section{Outcomes on Participants' Skills, Values, and Views}

In addition to institutional outcomes, informants perceive that PAFPOSE has influenced their own values, skills and thinking. In a brainstorming session on project outcomes held with members of the PAFOSE DMT, they identified new self-confidence in their own capacities as an important change brought about by their work with PAFOSE. Specifically, PAFOSE has given partners confidence to:

- Reach beyond their own organizations and view other organizations as potential partners rather than as potential competitors for scarce resources.

- Draw on each other's resources for expert knowledge rather than rely on outsiders.

- Develop new organizational and management processes as needed, rather than remain limited to what already exists.

The [PAFOSE] partnership has changed the traditional way in which partners approached food security issues and interventions in a compartmentalized manner, to a more holistic approach where the different partners work in a coordinated way and can easily tackle issues even when it is not their original profession. 


\section{Hgrizons}

This outcome is a result of the project's investment in skills building that was a major emphasis of the partnership project. Project participants credit the participatory design and management of the technical training workshops and food security interventions as the key to effective skills building. Participatory project design provided district partners, sub-county extension partners, and ACWs and other field partners with opportunities to develop their management capacities and skills to work outside traditionally bounded institutional structures, and the confidence that comes from developing and executing plans successfully. In addition, the content and activities of the participatory training workshops built partners' confidence and ease to conduct interactive, participatory group activities on sensitive topics, specifically HIV/AIDS and gender, and work comfortably with diverse people from different socioeconomic levels.

Training of partner members was a key investment as it prepared them for the partnership. I personally improved my skills in working with communities as a result of the training. Partnership is very empowering for communities as it allows them to express their own ideas confidently, and that makes people like me masters of community development! At the district level, PAFOSE has brought the district local government and the different agencies [TASO, LIRI] closer together.

PAFOSE district partner, District Community Development Department

\section{Household and Community Outcomes}

\section{HIV/AIDS-related stigma}

Although there are no quantitative measures of stigma reduction, most partners interviewed credit PAFOSE with improving people's openness about HIV while also reducing stigma in the communities where PAFOSE farmers' groups are based. In a sense, PAFOSE farmers' groups have become “community spaces” where HIV is openly discussed, with the effect of de-stigmatizing HIV.

I thank PAFOSE for encouraging open discussion especially about HIVAIDS. Because of this, stigmatization has gone way down and the windows have been thrown wide open. Now people feel free to come out, and are not afraid.

Female ACW or other field partner, Paya

It [PAFOSE] has opened the chance for people to really learn-and to come out openly about HIV serostatus. That means stigma has gone lower and lower.

Male ACW or other field partner, Busaba

I thank PAFOSE, because it has encouraged people to come openly to discuss issues, so now stigma is not very much with us.

Female ACW or other field partner, Busaba 
There are two reasons why the PAFOSE model may be effective in reducing stigma and in functioning as a platform for community-based HIV/AIDS communication and behavior change processes. First, because of the high quality of information and support on food security issues, membership in PAFOSE farmers' groups is desirable to everyone irrespective of HIV status, ${ }^{9}$ but the groups also openly incorporate HIV/AIDS into their mandate and are open about their mission of improving food security for HIV-affected households. Linking HIV to something everyone wants has the effect of normalizing HIV as a subject and reintegrating HIV-positive people back into the community fabric. Next, because HIV sensitization is integrated with giving people skills and resources to meet their food security needs, the disease itself may become less frightening, both to those who know their status and to those who do not. As fear goes down, people may become more open to learning about their status. In one sub-county (Paya), ACWs and other field partners indicated that they encourage testing in their groups and that members who do not know their status are beginning to go for testing as a result of sensitization in the groups.

[PAFOSE] has increased knowledge on farming; it has enabled us as farmers to work in groups; modern techniques for farming have been introduced to us, and people are more forthcoming, no longer shy to talk about HIV status.

Sub-county extension partner, Busaba

When one [with HIV] is sensitized on nutrition the health improves [and] they become selfsustaining [able to work again]. This encourages others to go for voluntary counseling and testing. TASO clients go to the clinic once or twice, but here at the grassroots [because of PAFOSE] it's a continuous flow of information.

Male ACW or other field partner, Paya

The subject of sexual behavior as a driver of the HIV epidemic did not come up in the interviews or discussions on which this case study is based, so the potential of the PAFSOE model to have an effect in this area requires further study. However, ACWs and other field partners and farmers in both sub-counties stated that participation in PAFOSE farmers' groups was having a positive effect on the quality of the relationships between husbands and wives and within families.

[PAFOSE has] helped [people] to realize good living together with wives, husband, and children, so now they are not like they used to be, they are more comfortable than before.

Female farmer group member, Busaba

Relationships within families is increased [improved] because now we men are consulting the women in issues concerning the food.

Male ACW or other field partner, Paya

\footnotetext{
${ }^{9}$ Since 2004 Uganda has had a policy of only allowing farmers to access extension services if they are members of registered farmers' groups, so farmers are either forming groups or looking for established groups to join. The groups have a legal status with officers and bylaws, and are registered with local district governments' Agricultural Production Departments.
} 


\section{Hgrizons}

\section{Gender relations}

We appreciate the gender intervention from the beginning. Gender has been a real problem within the homes. The project [PAFOSE] has given us a way of interacting on gender issues in the home. Nutrition, work-load in family, we now have a standard to talk to people and to sensitize them.

Female ACW or other field partner, Paya

Changes in gender relations perceived by informants include improved capacity for joint planning and decision making by husbands and wives. Some women report that their farming skills are being taken more seriously by men than before, as their "good ideas relating to farming are now welcomed and discussed seriously with the men," (female farmer group member, Paya) and husbands and wives are learning to plan based on estimates of the family food and income needs.

Previously, men would not let wives participate [in trainings] but after food security trainings, men have started releasing their wives. Now men and women [are] planning together.

Male ACW or other field partner, Busaba

Before [PAFOSE] a man could just sell and sell, without consulting the woman. But now they consult each other and come to a compromise before selling.

Male ACW or other field partner, Paya

Another change reported is greater participation of men in farming tasks that were previously left to women. In Busaba men from the PAFOSE farmers' groups have begun to work in the gardens with their wives, rather than spending most of the day in the local trading center participating in social activities, as they did before PAFOSE began to sensitize them on food security.

[PAFOSE] has helped us learn how to use time better. For example, the men used to drink [local beer] early in the morning. But now they work, and then they drink later.

Female ACW or other field partner, Busaba

ACWs and other field partners from both sub-counties report that men are beginning to help their wives with yam cultivation for their family, which used to be left entirely to women. 
One quarter acre of sweet potatoes will sustain a family for three months, and children like it because it is sweet. So husbands are now helping their wives find land and prepare the gardens. Husbands are also helping look for cuttings, because men are more mobile, and so can go farther to look for the best cuttings.

Male ACW or other field partner, Paya

Before PAFOSE, husbands ignored cultivating sweet potatoes because they regarded it as women's work. But these days they work together. Husbands and wives together open [the ground], heap, and plant.

Female farmer group member, Busaba

Even when men are still reluctant to do the actual farm work themselves, they are becoming more forthcoming with other forms of help to relieve wives' task management bottlenecks. The integrated way of thinking about food security promoted by PAFOSE has helped men understand that when women are overloaded by domestic chores, it impacts their ability to execute time sensitive tasks such as planting, weeding, harvesting, and post-harvest processing for storage, and this in turn reduces the yields households are able to realize.

[Before PAFOSE] men did not understand the gender problem in food security. Now they understand and have become involved in the work-they have come together and are working with the women.

Male ACW or other field partner, Busaba

At first [men doing women's work] felt shameful. But [people] soon realized that these were the real issues preventing enough food, so men came around. Men realized that all the burden is on women. So today, some of the families have changed and men are working in a new way.

Female ACW or other field partner, Busaba

ACWs and other field partners and farmers from both Busaba and Paya reported that men are beginning to take over porting water and cooking fuel for the family and are helping with child care, especially taking sick children to the clinic. Men are also beginning to take grain to the mill and paying to have it ground for the family, whereas before they expected their wives to grind it by hand.

In Busaba, these changes may be having a positive impact on household food production. As described by the sub-county extension partner, who is also a PAFOSE master trainer, joint decision making leads to better management and gives women a stake in their husbands' farms, so they work harder. Also, when men and women work together they hold each other to higher standards and are able to get more done than when they work alone. These factors can lead to better farming and higher yields, although the extent of the increase remains limited unless farmers can also source improved farming tools, labor saving technologies, seed, and other inputs. 


\section{Hgrizons}

Before, women resisted when they were told to do something. That is why food production declined. But now, when they share the decision making, they have come to do a good job.

Sub-county extension partner, Busaba

Many ACWs and other field partners and farmers identified domestic violence and stealing crops from family stores by angry spouses as social behaviors that contribute to household food insecurity. Much of these behaviors are driven by hostile relations between husbands and wives caused by wives being cut out of decisions about the sale of crops, use of income, and even what foods to cook for the family. However, according to informants, because of PAFOSE gender sensitization, men are slowly becoming less controlling.

What causes domestic problems in homes is because of food-when food is very small-as a man I take to sell and drink and don't leave enough for wife and children. When I come home, wife is angry, and there is violence... As a man, I take to sell, so women will respond by secretly selling, so you end up selling everything.

Male ACW or other field partner, Paya

There used to be losses of food in the home because men would sell. Then the wife would wait until the husband was gone, then she would sell secretly. In this way the food would disappear. Now we do the food together and in this way the food is saved.

Female farmer group member, Busaba

At household level, decision making has shifted from only men to even women now taking decisions, for example what food to eat.

Sub-county extension partner, Busaba

\section{Food management skills}

Many ACWs and other field partners and farmers reported that PAFOSE has helped them understand how wasteful cultural practices at harvest time, along with poor daily food management, contribute to food insecurity. PAFOSE ACWs and other field partners have taught simple techniques to help farmers estimate food quantities needed by different people (adults, HIV-affected adults, and children) and to plan how much food needs to be kept for the family in order to last until the next harvest comes in. Farmers are beginning to use these skills to plan the amount of food needed each day, which is also cutting down on waste. 
As a man I should know how much each person needs to eat each meal. I can calculate how much is needed and this can be saved for the family.

Male ACW, Paya

PAFOSE has helped us know how to use food in terms of quantity, so as to minimize wastage.

Female farmer group member, Busaba

[Before] we did not know that overselling of food can cause food insecurity, but due to the knowledge we got, we now understand that overselling of food can cause food insecurity, and we can really manage it now, by limiting it.

Female ACW, Paya

In our culture, the food we prepare after the harvest is like a mountain, so much is wasted. Now we can limit this...we can save [this food] to help us in the other phase [of the year when people are hungry].

Female ACW, Paya

In Paya, ACWs and other field partners and farmers indicated that women are starting to cook more times a day, both for improved nutrition and to avoid foods spoiling by being left too long. More frequent cooking however is also made possible because of the increased support women get from men, which frees time for food preparation. According to a Paya field partner, another improved food management behavior taught by PAFOSE is storing grain in the household using polyurethane sacks and chemicals to kill weevils.

\section{Understanding of nutrition and improved dietary diversity}

ACWs and other field partners and farmers in all six discussion groups emphasized that PAFOSE has helped them change family norms around equitable sharing of foods, especially eggs and chicken, so that women now freely eat both, including the portions of chicken that were formerly reserved for men. ACWs and other field partners and farmers also said that adults, especially women, are eating fruits on a regular basis, because they now understand their value as "protective foods." Along similar lines, ACWs and other field partners in Paya said they are encouraging their farmer group members to plant vegetables near their houses, and men are beginning to support their wives buying vegetables in the market when there are none in the gardens. As a result of these changes, ACWs and other field partners and farmers in both sub-counties reported experiencing improvements in their health, claiming that they are no longer sick as frequently, and that when they do get sick it is easier to recover. In Busaba, one male farmer reported, "We feel improvement in health and are not falling sick as often as before. This is because we are eating nutritious food and sharing it as a family." 


\section{Hgrizons}

There used to be a tradition that women should not eat chicken or eggs, but now with our [PAFOSE] sensitization that is down. Women are now free to eat chicken and eggs. With our sensitization women are [also] now eating the guavas, pawpaws, and mangos, and you can see how their health is improving.

Female ACW, Paya

One of TASO's objectives for the PAFOSE food security intervention has been to increase knowledge about HIV and nutrition and legitimize the special nutritional needs of HIV-positive people in the eyes of other household and community members. Although there was no specific probing on this topic during the group discussions with ACWs and other field partners or farmers, two people voluntarily spoke about their HIV status and their gratitude to PAFOSE for teaching them how to eat properly, which they both credited with a return of their strength and ability to farm.

Thanks especially to [the TASO counselor] for incorporating us [HIV-positive] people into the project, and for the good knowledge we are receiving, which is enabling us to eat food properly and to get a balanced diet. Because with a balanced diet some people are seeing good changes in us. Because people who used to stigmatize us, now they are seeing some differences in us. Now we are able to dig, and to do those things which are making them surprised. And now we just pray that now we are incorporated we are going to further fight the problem of food insecurity and therefore we have that vision that our lives will be prolonged.

Female ACW, Paya

It is important to keep in mind that the outcomes noted are qualitative impressions based on perceptions of project participants into what is a dynamic process of changing cultural norms and behaviors. More rigorous research is needed to determine the extent to which attitudes and behaviors have changed, and the types of households making these changes. When probed about how widespread the behavior changes catalyzed by PAFOSE were, partners agreed that some of the behaviors, especially those relating to gender, change slowly. But they also affirmed vigorously that they are changing, and that ACWs and other field partners and members of PAFOSE farmers' groups are becoming positive role models for the wider community. 
Improving the Food Security of HIV-affected Households

\section{Discussion}

Policy and programming in nutrition, food security and HIV/AIDS includes two approaches: the first seeks to improve the nutrition of people living with HIV in the context of health care delivery systems; the second seeks to improve their nutrition in the context of their households and communities. The second approach recognizes that food behavior, like sexual behavior, is influenced by the knowledge, skills, resources, and norms of families and communities. To be sustainable (so that malnutrition does not reoccur when food aid is withdrawn), HIV food and nutrition interventions must be integrated into households and communities where affected people live. This means that family and community members must also gain the knowledge, skills, and resources needed to manage the nutritional needs of people living with HIV in the context of overall household food security.

Within Africa there is a growing movement comprising practitioners at the front lines of the AIDS epidemic who are demanding that policymakers "bridge the divide between the worlds of food and nutrition security and the HIV/AIDS response” (Project Concern 2006). At a meeting convened in Lusaka, Zambia in May 2006, a group of these practitioners met and generated a consensus document, which came to be known as the Lusaka Declaration. This document states the following:

Throughout Africa, communities, local organizations, governments and HIV-positive people themselves are developing innovative approaches to improving food and nutrition security for those affected by HIV\&AIDS. Front line practitioners, aware of the realities in which HIVpositive people live, are demanding that the international community invest now in identifying and enabling rapid scale-up of effective integrated programming while insuring that local initiative is not undermined and dependencies created (Project Concern 2006).

The case study of the PAFOSE Project in Tororo, which is the subject of this report, provides the policy community with an example of front line practitioners' efforts to develop local institutional capacity to design, implement, and manage integrated, community-based responses to HIV/AIDS and food security.

\section{What has PAFOSE Accomplished Through its Partnership Model?}

There is wide recognition in Uganda of the need to plan and coordinate development efforts more effectively between agencies working at the district and sub-county levels in order to avoid duplication of effort, to take advantage of synergies between capacities and resources of different organizations, and to avoid fragmentation of service delivery at the community level. In the HIV policy arena this recognition is evidenced by the formation of HIV advisory committees in many districts made up of top representatives from the three branches of district government, INGOs, NGOs and service delivery organizations such as TASO.

Despite this awareness, there are few examples of how to move from recognition of the need to bring agencies together to focus on problems in their communities as a team rather than as competitors. The PAFOSE Project in Tororo has gone beyond a conceptual model to operationalize actual principles, processes, and procedures for linking organizations that builds on each organization's strengths. TASO has successfully grafted its field organization onto the technical branch of local government through the coordinated extension model, with significant benefits both for TASO's clients and for extension. Although NARO is not technically part of the agricultural extension system, it is dependent on extension 


\section{Hgrizons}

to disseminate its technologies, so NARO's institutional objectives have been furthered by improvements in extension's capacity to reach poor and HIV-affected households.

\section{Why has PAFOSE Worked as a Partnership?}

From the start TASO and District Local Government's technical agencies' willingness to support the project came from recognition by their department heads that their core objectives could best be served through partnership, and so each one was willing to develop interdependency with the others. Institutional support has given the partners legitimacy to create new models for how business can be conducted at the sub-county level and with farmers' groups; sub-county extension agents, TASO ACWs, and registered farmers' groups now come together knowing that their actions are supported by each of their own organizations at higher levels. The interdependency and legitimacy provided by the heads of TASO, NARO-LIRI, and District Local Government technical branches have created an enabling environment where district partners have built trust in each other and belief and confidence in their own capacities as the project has unfolded.

In addition to support, partners have had autonomy to implement a new management model. PAFOSE derives its strengths from the network of institutions involved in the partnership which provide committed structures and resources, but at the same time the network creates space for PAFOSE to work more or less independently in implementing its activities, while at the same time maintaining the linkages between institutional stakeholders through application of partnership principles. In addition, participating organizations are beginning to sign Memorandums of Understanding formalizing their roles in the partnership, the first one being between TASO and NARO-LIRI, which was signed in the summer of 2006.

\section{Next Steps for PAFOSE}

When farmers and ACWs and other field partners were asked what they wanted from PAFOSE in the future, they stated more high quality, integrated information of the sort delivered in the four training modules, so this may be needed to maintain the partnership's comparative advantage as an integrating mechanism at the sub-county and local levels. In addition to information, if it is to remain credible at the local level the partnership needs to begin delivering technical inputs to help farm households improve their agricultural productivity and incomes. So the sustainability of the partnership depends on the project's success in delivering and supporting the uptake of technical interventions to improve farming practices, productivity, and ultimately food security and incomes among HIV-affected small holder farmers. This phase of the project is just beginning, but if the partnership is more successful in this regard than traditional extension, it will be a significant advance for stakeholders focused on broader poverty alleviation issues, as well as for HIV service delivery organizations such as TASO. If the project is successful at this level, partnership could become a viable institutional mechanism for many different sectors and agencies to deliver technical inputs in ways that benefit HIV-affected communities, even if they are not funded by HIV-related organizations.

When looked at in terms of improved information, services, and input delivery to communities, the gains from partnership may far outweigh the costs incurred by building staff time into local organizations to handle partnership-related activities. Another way of putting it, the incremental additions to staff budgets needed to link institutions together to leverage each other's institutional strengths is far less than the costs 
of each institution trying to replicate the other's strengths internally. For example, the costs to Uganda's Ministry of Agriculture to develop and support its own field staff at the local community level, to fill the function that TASO's ACWs fill in the coordinated extension model, would be prohibitive, not to mention that it would also require a whole shift in institutional culture from didactic to participatory, which could take years to achieve if it were mandated from the top down.

The PAFOSE partners in Tororo are focusing on the sustainability of the partnership approach and have identified advocacy for the partnership model as a key activity of their next phase of work, in addition to implementing and monitoring the delivery of technical inputs to the PAFOSE farmers' groups. PAFOSE partners began their advocacy in September 2006 with visits to Tororo's Chief Executive Officer and his cabinet, who were extremely interested in the project's activities in the three intervention sub-counties. In response, the district council cabinet has indicated that PAFOSE will be allocated time during council sessions to brief the council members on the project, its activities, and its successes/challenges. This is a sign of good will and support from the political leadership, which is a gateway to the communities.

With continued support from individuals committed to the project, especially at TASO, NARO-LIRI, and ICRW, the District partners will develop additional confidence and skills to advocate for the partnership model within the district's broader governance processes, with the goal of extending coordinated extension to other sub-counties in the district, as part of the district's way of doing business. Advocacy to institutionalize PAFOSE's activities is also coming from the sub-county government structures. The Paya sub-county council has included PAFOSE activities in its work-plan and budget for 2007, which is submitted to the district council for funds, ensuring the seeds of sustainability are firmly planted through institutionalization of this project.

The sub-county has entrusted me to help with integrating all the parish and departmental plans into the 3-year rolling plan. Consequently, even PAFOSE is now integrated into the sub-county rolling plan.

Sub-county extension partner Paya

In addition, the PAFOSE partners will need to work closely with the district and sub-county local governments in Tororo, Busaba, Paya, and Osukuru to develop a framework (or preferably build into an existing one) for monitoring the project and its impact on the communities as well as on the institutions involved. This monitoring framework should focus on key aspects of food security, especially the following:

- Capacity for partnership at all levels

- Coordination of extension workers

- Extension agents' education and awareness of HIV/AIDS

- Impact of this model of extension on levels of HIV-related stigma

- Changes in gender roles and nutrition practices

- Implementation progress of food security interventions

- Uptake of technologies

- Impact of this model of extension on food security of HIV-affected households

- Sustainability and replication of this model of extension 


\section{Hgrizons}

Simple monitoring tools and indicators for each aspect above can be developed in a participatory manner, with emphasis on identifying those indicators that the community can easily use to monitor and respond to at the household and farmers group levels. The existence of such a monitoring framework would give a strong foundation for communities to quickly take action on issues on their own, while learning lessons which can be shared with other communities who might want to tackle food security problems using the PAFOSE approach. At the institutional level, a monitoring framework and database can facilitate oversight of the project by the partners and joint actions in response to problems. Such a database can also be shared at national and other levels.

\section{Main Messages and Lessons Learned}

\section{Capacity for partnership must be built at multiple levels.}

A key lesson of the PAFOSE partnership is that inter-sectoral partnerships between organizations to leverage different sets of expertise and skills for common goals is feasible and practical, but it is essential that management capacity for partnership be built at all institutional levels, and that the process is participatory at all levels. Many development projects have capacity building as an underlying principle, but the assumption is often made that the capacities that need to be built are those "in the community." The gaps in capacity among the project partners themselves—and among high-level partners—is not as readily acknowledged, and even less often addressed directly through capacity building and training. A key strength of this project is that it took as its starting point the need to create the capacity for partnership at all levels. In particular, building partners' capacities to facilitate participatory group process was emphasized at every level, and has been an important element in building confidence and trust between district partners, sub-county extension partners, ACWs and other field partners, and farmers.

\section{Coordination around HIV and agriculture is valuable to both groups.}

The PAFOSE process has clearly shown that the coordination of agricultural extension and HIV/AIDS education and awareness can enhance the outcomes of both sets of activities. The integration of these two models into one functional community outreach system enables the delivery of high quality information on agricultural practices, HIV and AIDS, and their inter-relationships directly to community membersincluding vulnerable and HIV-affected households - via the farmer's group mechanism. This process extends the reach of an over-stretched agricultural extension service and provides TASO with the opportunity to develop the necessary long-term relationships with households through which they can provide truly substantive HIV and AIDS-related support.

\section{Agricultural extension provides a non-stigmatizing context to deliver HIV-related information and services.}

Another lesson is the importance of linking HIV/AIDS education, information, and sensitization activities with interventions that are non-stigmatizing and which relate directly to issues that impact people's ability to sustain their livelihoods. By participating in the farmers' groups and engaging with farmers meaningfully in discussions of farming practices and nutrition, a rapport is developed between the farmers and the TASO ACWs that might not otherwise have emerged. This rapport may make farmers 
feel more comfortable to ask questions and to learn more about HIV, their own risk, and/or treatment and care options. Moreover, when learning about HIV in the context of the farmers' groups, participants are also being provided with the tools, knowledge, and technologies they need to help ensure their food security even in the face of HIV/AIDS.

\section{Gender inequality was understood as limiting food security.}

As reported by informants, the PAFOSE Project has put discussions of gender equity into a meaningful context, which may be leading to changes in behavior and increased equity in gender relations. As part of project activities, participants in the PAFOSE farmers' groups analyzed gender relations in the context of household food security - a topic of salience in their everyday lives. They themselves identified key gender-related obstacles to their household food security and began a shift toward supporting more gender-equitable attitudes. The motivation for making these changes came from the understanding that reducing gender inequities would have a direct benefit in terms of their household's food security. The lesson here is that increasing support for gender equitable norms is possible when the context is relevant and the benefit of change is clear to all involved. 


\section{Hgrizons}

\section{References}

du Guerny, J. 1999. “AIDS and agriculture in Africa: can agricultural policy make a difference?” FNA/ANA 25.

ftp://ftp.fao.org/docrep/fao/X4390t/X4390t03.pdf

Accessed May 22, 2007

IFAD 2007. Uganda Statistics. Rural Poverty Portal.

http://www.ruralpovertyportal.org/english/regions/africa/uga/statistics.htm

Accessed May 22, 2007

Kayita, J. 2002. "HIV care and support in resource-constrained settings: a focus on food and nutrition," paper delivered at Food Security and HIV/AIDS Programming meeting, Washington D.C., January 2002.

Ministry of Health [Uganda] and ORC Macro. 2006. Uganda HIV/AIDS Sero-Behavioural Survey 20042005. Calverton, MD: Ministry of Health and ORC Macro.

Project Concern. 2006. "Declaration on the dual epidemics of HIV\&AIDS and food insecurity.” Africa Forum website.

http://www.projectconcern.org/site/PageServer?pagename=2006_Africa_Forum

http://www.projectconcern.org/site/DocServer?docID=166

Accessed May 22, 2007

Ravnborg, Helle Monk et al. 2004. "Gendered district poverty profiles and poverty monitoring Kabarole, Masaka, Pallisa, Rakai and Tororo districts, Uganda,” DIIS Working Paper. Denmark: Danish Institute for International Studies.

Ugandan Aids Commission et al. 2000. "National strategic framework for HIV/AIDS activities in Uganda, 2000/1-2005/6,” Report. Uganda: The Republic of Uganda.

UNAIDS. 2007. Uganda Country Situation Analysis. Geneva: UNAIDS.

http://www.unaids.org/en/Regions_Countries/Countries/Uganda.asp

Accessed April 24, 2007 


\section{Appendix 1}

\section{District level workshops in Tororo Municipality: attended by district partners and sub- county extension partners}

\begin{tabular}{|c|c|c|c|c|}
\hline Title & $\begin{array}{l}\text { Principles of } \\
\text { partnership }\end{array}$ & $\begin{array}{l}\text { Technical skills } \\
\text { and knowledge } \\
\text { sharing }\end{array}$ & $\begin{array}{l}\text { Understanding } \\
\text { causes of food } \\
\text { insecurity and } \\
\text { identifying } \\
\text { interventions }\end{array}$ & $\begin{array}{l}\text { Identifying technical } \\
\text { food security } \\
\text { interventions }\end{array}$ \\
\hline Date held & April 2004 & June 2004 & April 2005 & April 2006 \\
\hline Objectives & $\begin{array}{l}\text { 1. Establish } \\
\text { partnership } \\
\text { principles and } \\
\text { procedures } \\
\text { 2. Develop } \\
\text { integrated } \\
\text { understanding of } \\
\text { food security } \\
\text { 3. Develop master } \\
\text { trainers skills in } \\
\text { participatory process } \\
\text { 4. Develop plans and } \\
\text { manuals for ACWs } \\
\text { and other field } \\
\text { partners trainings }\end{array}$ & $\begin{array}{l}\text { 1. Share technical } \\
\text { specialties to make } \\
\text { partners holistically } \\
\text { knowledgeable } \\
\text { 2. Give master } \\
\text { trainers confidence } \\
\text { to speak about each } \\
\text { other's specialties } \\
\text { when conducting } \\
\text { trainings for ACWs } \\
\text { and other field } \\
\text { partners }\end{array}$ & $\begin{array}{l}\text { 1. Analyze causes of } \\
\text { food insecurity in } \\
\text { Tororo } \\
\text { 2. Identify coping } \\
\text { mechanisms within } \\
\text { communities } \\
\text { 3. Identify interventions } \\
\text { (social and technical) } \\
\text { and action plans } \\
\text { 4. Develop master } \\
\text { trainers' skills to teach } \\
\text { analysis and action } \\
\text { planning to ACWs and } \\
\text { other field partners }\end{array}$ & $\begin{array}{l}\text { 1. Prioritize and rank } \\
\text { technical } \\
\text { interventions } \\
\text { identified by ACWs } \\
\text { and other field } \\
\text { partners working } \\
\text { together with } \\
\text { PAFOSE farmers' } \\
\text { groups } \\
\text { 2. Develop plans for } \\
\text { technical support, } \\
\text { monitoring and } \\
\text { evaluation of } \\
\text { technical } \\
\text { interventions }\end{array}$ \\
\hline Participants & $\begin{array}{l}20 \text { district and sub- } \\
\text { county extension } \\
\text { partners (including } \\
\text { all } 9 \text { master trainers) }\end{array}$ & $\begin{array}{l}20 \text { district and sub- } \\
\text { county extension } \\
\text { partners (including } \\
\text { all nine master } \\
\text { trainers) and experts } \\
\text { from FAO, MOH, } \\
\text { NARO, NAADS (5 } \\
\text { total) }\end{array}$ & $\begin{array}{l}\text { Only the } 9 \text { district and } \\
\text { sub-county partners } \\
\text { who were also the } \\
\text { master trainers }\end{array}$ & $\begin{array}{l}15 \text { district and sub- } \\
\text { county extension } \\
\text { partners (including all } \\
9 \text { master trainers) }\end{array}$ \\
\hline $\begin{array}{l}\text { Manuals } \\
\text { produced }\end{array}$ & $\begin{array}{l}\text { 1. "Training Guide } \\
\text { for Training ACWs } \\
\text { and other field } \\
\text { partners" } \\
\text { 2. "Joining Hands to } \\
\text { Improve Food } \\
\text { Security-ACWs and } \\
\text { other field partners } \\
\text { Manual" }\end{array}$ & & $\begin{array}{l}\text { 1. "Trainers Guide for } \\
\text { Training ACWs and } \\
\text { other field partners: } \\
\text { Intervention Planning" } \\
\text { 2. "Guide for ACWs } \\
\text { and other field } \\
\text { partners: Farmers } \\
\text { Group Meetings- } \\
\text { Selecting } \\
\text { Interventions" }\end{array}$ & $\begin{array}{l}\text { 1. ACWs and other } \\
\text { field partners Training } \\
\text { Manual covering } \\
\text { technical aspects of } \\
\text { identified } \\
\text { interventions }\end{array}$ \\
\hline Follow-up plans & $\begin{array}{l}\text { To conduct first and } \\
\text { second round } \\
\text { training workshops } \\
\text { for ACWs and other } \\
\text { field partners }\end{array}$ & & $\begin{array}{l}\text { To conduct third round } \\
\text { training workshops for } \\
\text { level two trainers, } \\
\text { ACWs and other field } \\
\text { partners }\end{array}$ & $\begin{array}{l}\text { Conduct ongoing } \\
\text { technical training/ } \\
\text { support/M\&E } \\
\text { workshops for ACWs } \\
\text { and other field } \\
\text { partners }\end{array}$ \\
\hline
\end{tabular}


Sub-county trainings in sub-county centers: attended by master trainers and ACWs and other field partners

\begin{tabular}{|c|c|c|c|c|c|}
\hline Title & $\begin{array}{l}\text { Round one } \\
\text { training }\end{array}$ & $\begin{array}{l}\text { Round two } \\
\text { training }\end{array}$ & $\begin{array}{l}\text { Round three } \\
\text { training }\end{array}$ & $\begin{array}{c}\text { PAFOSE } \\
\text { technical } \\
\text { interventions }\end{array}$ & Ongoing trainings \\
\hline Date held & April 2004 & $\begin{array}{l}\text { June } 2004 \\
\text { (refresher round } \\
\text { two trainings } \\
\text { held March } \\
\text { 2005) }\end{array}$ & $\begin{array}{c}\text { April and October } \\
2005\end{array}$ & April 2006 & $\begin{array}{c}\text { Began December } \\
2006\end{array}$ \\
\hline $\begin{array}{l}\text { Training } \\
\text { Objectives } \\
\text { and Content }\end{array}$ & $\begin{array}{l}\text { 1. Introduce } \\
\text { Partnership } \\
\text { principles and } \\
\text { procedures to } \\
\text { ACWs and } \\
\text { other field } \\
\text { partners } \\
\text { 2. Develop } \\
\text { ACWs and } \\
\text { other field } \\
\text { partners' } \\
\text { integrated } \\
\text { understanding } \\
\text { of food security } \\
\text { 3. Develop } \\
\text { ACWs and } \\
\text { other field } \\
\text { partners' skills } \\
\text { in participatory } \\
\text { process }\end{array}$ & $\begin{array}{l}\text { 1. Develop } \\
\text { ACWs and } \\
\text { other field } \\
\text { partners' skills } \\
\text { in situation } \\
\text { analysis for food } \\
\text { insecurity } \\
\text { 2. Develop } \\
\text { ACWs and } \\
\text { other field } \\
\text { partners' skills } \\
\text { in action } \\
\text { planning based } \\
\text { on situation } \\
\text { analysis } \\
\text { 3.Develop } \\
\text { ACWs and } \\
\text { other field } \\
\text { partners' skills } \\
\text { in farmer group } \\
\text { mobilization and } \\
\text { support }\end{array}$ & $\begin{array}{l}\text { 1. Identify causes } \\
\text { of food insecurity } \\
\text { 2. Identify } \\
\text { community coping } \\
\text { mechanisms } \\
\text { 3. Identify social } \\
\text { and technical } \\
\text { interventions } \\
\text { 4. Develop ACWs } \\
\text { and other field } \\
\text { partners' skills to } \\
\text { conduct this } \\
\text { analysis and } \\
\text { identification with } \\
\text { farmers' groups }\end{array}$ & $\begin{array}{l}\text { 1. Develop list } \\
\text { of technical } \\
\text { interventions for } \\
\text { the PAFOSE } \\
\text { district team }\end{array}$ & $\begin{array}{l}\text { 1. Teach ACWs and } \\
\text { other field partners' } \\
\text { how to use Training } \\
\text { Manual covering } \\
\text { technical } \\
\text { interventions } \\
\text { 2. Provide support } \\
\text { for interventions } \\
\text { 3. Monitor and } \\
\text { evaluate } \\
\text { interventions }\end{array}$ \\
\hline Participants & $\begin{array}{l}24 \mathrm{ACW} \text { and } \\
\text { other field } \\
\text { partners and } 3 \\
\text { master trainers } \\
\text { per sub-county }\end{array}$ & $\begin{array}{l}24 \mathrm{ACW} \text { s and } \\
\text { other field } \\
\text { partners and } 3 \\
\text { master trainers } \\
\text { per sub-county }\end{array}$ & $\begin{array}{l}24 \mathrm{ACW} \text { and } \\
\text { other field } \\
\text { partners and } 3 \\
\text { master trainers } \\
\text { per sub-county }\end{array}$ & $\begin{array}{l}24 \text { ACWs and } \\
\text { other field } \\
\text { partners, } 3 \\
\text { master trainers } \\
\text { and } 9 \text { PAFOSE } \\
\text { farmers' groups } \\
\text { per sub-county }\end{array}$ & $\begin{array}{l}\text { PAFOSE district } \\
\text { and sub-county } \\
\text { extension partners, } \\
\text { ACWs and other } \\
\text { field partners and } \\
\text { farmers' groups } \\
\text { (ongoing) }\end{array}$ \\
\hline
\end{tabular}




\section{Appendix 2 Agenda for PAFOSE Trainer of Trainer's Workshop, Tororo, Uganda April 13- 20, 2004}

\section{Workshop Sessions}

1. Opening Activities

2. Picture Drawing as Partners

3. Understanding Partnership

4. Deepening Analysis on Partnership

5. Partnership Bingo

6. Food Security Problems (Card-storm)

7. Food Security Analysis (Group Work)

8. Sharing Experiences on Partnership

9. Secret Admirer

10. Planning Our Field Work Strategy

11. Analysis of Farmers' groups

12. Design of Field Partner Training

13. Designing Training Modules

14. Project and Partner Profiles

15. Training and Facilitation Techniques

16. Team Planning for Field Partner Training

17. Impact of Project in Three Years

18. Joining Hands with the Research Team

19. Strategy for Community Outreach

20. Partnership Model and Plan

21. Gives (Offers), Gets (Needs)

22. Roles of Different Partners 


\section{Appendix 3 \\ Results Framework and I ndicators of the Partnership}

\begin{tabular}{|c|c|}
\hline Results Framework for Partnership Intervention & Key Indicators for the Partnership Intervention \\
\hline $\begin{array}{l}\text { - Develop a clear statement of roles and } \\
\text { responsibilities for each partner } \\
\text { - Share information and experience between } \\
\text { partners on a regular basis } \\
\text { - Discuss and agree on the need for the } \\
\text { partnership, its goals and objectives, and its } \\
\text { purpose and its membership } \\
\text { - Include partnership activities in own agency or } \\
\text { department work plans } \\
\text { - Involve partners in planning, monitoring, and } \\
\text { evaluation } \\
\text { - Get to know each other through meetings and } \\
\text { sharing } \\
\text { - Coordinate partner activities } \\
\text { - Raise and solve conflicts }\end{array}$ & $\begin{array}{l}\text { - A clear statement of the roles and } \\
\text { responsibilities of each partner that is } \\
\text { available } \\
\text { - Evidence of regular sharing of information } \\
\text { and experience between partners } \\
\text { - Agreed goals and objectives of the } \\
\text { partnership and what the partnership is } \\
\text { about, including a membership MOU } \\
\text { - Presence of partnership activities in each } \\
\text { member's own agency or department work } \\
\text { plans } \\
\text { - Partners involved in planning, monitoring, } \\
\text { and evaluation } \\
\text { - Good knowledge of each other through } \\
\text { meetings and sharing } \\
\text { - Coordinated partner activities } \\
\text { - Conflicts, if any, discussed and solutions } \\
\text { found }\end{array}$ \\
\hline
\end{tabular}




\section{Hgrizons}

Horizons is a global operations research program designed to:

- Identify and test potential strategies to improve HIV/AIDS prevention, care, and support programs and service delivery.

- Disseminate best practices and utilize findings with a view toward scaling up successful interventions.

\section{(2) Population Council}

Horizons is implemented by the Population Council in collaboration with

- International Center for Research on Women (ICRW)

- International HIV/AIDS Alliance

- PATH

- Tulane University

- Family Health International (FHI)

- Johns Hopkins University

For more information, please contact:

Horizons Program, Communications Unit 4301 Connecticut Avenue, NW Suite 280 Washington, DC 20008 USA

Tel: 202-237-9400

Fax: 202-237-8410

Email: horizons@popcouncil.org www.popcouncil.org/horizons 